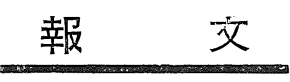

\title{
ミンク鯨油の性状成分について
}

上野誠一*。松島健 児*

\section{On the Composition of the Balaenoptera \\ acto-rostrata Lacépède Oil}

Sei-ichi Ueno and Kenji Matsushima

ミンク鯨は一名コイワシク ジ (Lesser Rorqual, Piked Whale) Balaenoptera acto-rostrata Lacépède と称し, ナガス鯨科嘱する。本科中の最小種で, 体長 8〜10 m, ナガス鯨の幼児似ているが，胸ヒレ背面の 白色横帯の鮮在が特徵である。南北雨半球と分布し, わ が国でも多少捕獲される。

この実験の試料は北海道産である。

試用したミンク鯨油は淡黄色透明の液体でつぎの性状 を有した。

$d_{4}^{15} 0.9270 \quad n_{\mathrm{D}}^{20} 1.4725 \quad$ 酸価 6.7

ケン化価 190.3 ヨウ素価（ウィイス法） 145.2

油より得た総脂肪酸および不ヶン化物の性状はつぎの と括りである。

総脂肪酸 $92.9 \%$, 中和価 191.3

ヨウ素価（ウィイス法） 143.2

不ケン化物の性状はつぎのと招りである。

$n_{\mathrm{D}}^{20} 1.4688$ ヨウ素価（ウィイス法） 120.1

アセチル価 218.4

固体脂肪酸および液体脂肪酸の分離

上記のようにして製収した総脂肪酸を常法鉛塩アルコ 一ル法により, 固体酸和よび液体酸を分離した結果は 表-1 のと捛りである。

表-1

\begin{tabular}{|c|c|c|c|c|c|}
\hline & $\begin{array}{l}\text { 収量 } \\
(\mathrm{g})\end{array}$ & $\begin{array}{l}\text { 収率 } \\
(\%)\end{array}$ & 中和値 & $\begin{array}{l}\text { ヨウ素価 } \\
\text { (ウイイス法) }\end{array}$ & 融点 $\left({ }^{\circ} \mathrm{C}\right)$ \\
\hline 固 体 酸 & 63 & 16.4 & 213.5 & 12.4 & $46.7 \sim 49.5$ \\
\hline 液体酸 (1) & 281 & 73.5 & 186.1 & 146.3 & \\
\hline (2) & 22 & 5.7 & 195.6 & 111.6 & \\
\hline
\end{tabular}

このときの実験損失量 $4.4 \%$

液体酸は橙黄色，固体酸は白色であった。上表中液体 酸（1）は第 1 回沈殿のときの母液，（2）は再沈殿の 際の母液より収得した液体酸である。以後の検索には液 体酸（1）を用いた。

液体酸 (1) 招よび固体酸をそれぞれメチルエステル

* 近畿大学理工学部 (大阪府布施市小若江)

Kinki University, Faculty of Science and Technology
とし，固体酸捛よび液体酸の検索を行った。

\section{固体酸の検索}

上記の固体酸をメチルエステルとし， $37 \mathrm{~g}$ のメルエ ステルを得た。これをクライゼン型蒸留フラスコで減圧 蒸留を行った結果は 表-2 のと拾りである。

表-2

\begin{tabular}{|c|c|c|c|c|c|}
\hline 留分番号 & 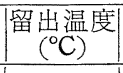 & $\begin{array}{c}\text { 压 力 } \\
(\mathrm{mmHg})\end{array}$ & 収量 $(\mathrm{g})$ & ケン化価 & $\begin{array}{l}\exists \text { ウ素 } \\
\text { (ウ1イス }\end{array}$ \\
\hline (1) & $132 \sim 158$ & 8 & 7.9 & 233.1 & 1.4 \\
\hline (2) & $159 \sim 162$ & 8 & 16.0 & 218.0 & 0.2 \\
\hline (3) & $163 \sim 167$ & 8 & 7.5 & 202.9 & 5.9 \\
\hline (4) & $168 \sim$ & 8 & 3.7 & 182.6 & 21.3 \\
\hline $\begin{array}{l}\text { 残サ括よ } \\
\text { び損失 }\end{array}$ & & & 1.9 & & \\
\hline
\end{tabular}

このなかの留分 (2) をラーデンブルグ型蒸留フラス コでさらに減圧蒸留し 表-3 の結果を得た。

表-3

\begin{tabular}{|c|c|c|c|c|c|c|}
\hline $\begin{array}{l}\text { 留分 } \\
\text { 番号 }\end{array}$ & $\begin{array}{c}\text { 留出温度 } \\
\left({ }^{\circ} \mathrm{C}\right)\end{array}$ & $\begin{array}{c}\text { 圧力 } \\
(\mathrm{mm} \\
\mathrm{Hg})\end{array}$ & $\begin{array}{c}\text { 留出量 } \\
(\mathrm{g})\end{array}$ & $\begin{array}{l}\text { ケン } \\
\text { 化価 }\end{array}$ & $\begin{array}{l}\text { ヨ门素価 } \\
\left(\begin{array}{l}\text { ウ1イ } \\
\text { ス法 }\end{array}\right)\end{array}$ & $\begin{array}{l}\left.\text { 融 }{ }^{\circ} \mathrm{C}\right)^{\text {点 }} \\
\end{array}$ \\
\hline (2) -1 & $151 \sim 160$ & 9.0 & 6.8 & 216.8 & 2.1 & $\begin{array}{r}21.0 \sim \\
23.2\end{array}$ \\
\hline (2) -2 & $161 \sim 172$ & 9.0 & 7.2 & 211.8 & 1.2 & $\begin{array}{r}26.3 \sim \\
27.0\end{array}$ \\
\hline (2) -3 & $173 \sim$ & 9.0 & 1.2 & 186.7 & 5.1 & 22.2 \\
\hline 残サ & : & & 0.6 & & & \\
\hline
\end{tabular}

上表の固体酸メチルの各留分をケン化後, 酸で分解し $70 \sim 80 \%$ エタノールより数回再結晶させ融点を測定し, また混融試験を行った結果は表-4 のと和りである。

表-4

\begin{tabular}{|c|c|c|c|}
\hline \multirow{2}{*}{ 留分番号 } & \multirow{2}{*}{$\begin{array}{l}\text { 再結晶後 } \\
\text { 融点 } \\
\left(\mathrm{C}_{16} \text { 融点) }\right.\end{array}$} & \multirow{2}{*}{$\begin{array}{l}\text { 再結晶後 } \\
\text { の中和価 }\end{array}$} & 混 融 試 験 \\
\hline & & & $\mathrm{C}_{18}$ \\
\hline (1) & $\left|\begin{array}{c}54.5 \sim 58.2 \\
(64.0)\end{array}\right|$ & 219.9 & $61.5 \sim 64.567 .8 \sim 71.5$ \\
\hline (2) -2 & $\begin{array}{c}59.5 \sim 61.6 \\
(64.0)\end{array}$ & 220.9 & $58.6 \sim 62.3$ \\
\hline (3) & $54.5 \sim 58.5$ & 213.1 & $58.2 \sim 58.4$ \\
\hline (4) & $54.3 \sim 63.5$ & 184.5 & $59.6 \sim 67.0$ \\
\hline
\end{tabular}




\section{液体酸メチルの分留}

上記のよろにして得た液体酸 (1) メチルの一部 $130 \mathrm{~g}$ を減圧蒸留した結果を表一敂にす。

\section{表-5}

\begin{tabular}{|c|c|c|c|c|c|}
\hline 留分番号 & $\begin{array}{c}\text { 留出温度 } \\
\left({ }^{\circ} \mathrm{C}\right)\end{array}$ & $\begin{array}{l}\text { 压 力 } \\
(\mathrm{mmHg})\end{array}$ & 収量 (g) & ケン化価 & $\left(\begin{array}{l}\exists \text { ウ素価 } \\
\text { ウ法 }\end{array}\right)$ \\
\hline (1) & $\sim 159$ & 6 & 24.2 & 214.4 & $110: 9$ \\
\hline (2) & $160 \sim 169$ & " & 18.3 & 206.4 & 112.4 \\
\hline (3) & $170 \sim 179$ & " & 31.4 & 199.8 & 160.7 \\
\hline (4) & $180 \sim 188$ & " & 23.1 & - & 134.2 \\
\hline (5) & $189 \sim 194$ & "I & 18.9 & 189.7 & 187.7 \\
\hline (6) & $194 \sim$ & " & 1.5 & 179.3 & 202.1 \\
\hline $\begin{array}{l}\text { 残サ执よ } \\
\text { び損失量 }\end{array}$ & & & 12.6 & & \\
\hline
\end{tabular}

\section{液体酸の検索}

臭化法 液体酸 (1) のメチルエステル $46.9 \mathrm{~g}$ を 5 倍量のエーテル溶液とし, 氷冷下に和いて臭素滴下法 に上り臭素化を行った。沈殿した六臭化物以上をロ別し たロ液は過剩の臭素をチオ硫酸ナトリウム液で洗浄し，

よく水洗ののち，エーテルを留去し残留物を石油エーテ ル（沸点 $46^{\circ} \mathrm{C}$ 以下） で処理し，可溶性の二臭化物（和 よび微量の飽和酸）を，不溶性物四臭化物と分別した。

エーテルに不溶性沈殿である兵臭化物以上の高度不飽 和酸臭化物は，白色の沈殿であるが，これを熱ベンゼン で処理し，溶解した六臭化物を分別口過した。これら各 臭化物の性状は 表-6 に示したと拉りであった。

\section{表-6}

\begin{tabular}{|c|c|c|c|c|c|c|}
\hline 臭 化 物 & $\left|\begin{array}{|c|}\mid \text { 收量 } \\
(\mathrm{g})\end{array}\right|$ & 状態 & 色 & 融点 $\left({ }^{\circ} \mathrm{C}\right)$ & 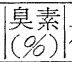 & 加熱試験 \\
\hline$\left(\begin{array}{l}\text { 二臭化物 } \\
\text { 石油可溶性 }\end{array}\right)$ & 54.8 & 液体 & $\begin{array}{l}\text { 黒カッ } \\
\text { 色 }\end{array}$ & - & 39.9 & $\begin{array}{l}50^{\circ} \mathrm{C} て ゙ \\
\text { 黑変 }\end{array}$ \\
\hline $\begin{array}{l}\text { 四臭化物 } \\
\left(\begin{array}{c}\text { エ テル可 } \\
\text { 溶性 }\end{array}\right)\end{array}$ & 93.0 & アメ状 & カッ色 & $50 \sim 53$ & 60.6 & $\begin{array}{l}100^{\circ} \mathrm{C} \\
\text { で変色 }\end{array}$ \\
\hline 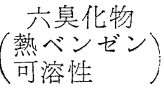 & 27.0 & 固体 & 淡黄色 & $130 \sim 132$ & 67.1 & $\begin{array}{l}\text { 毕較的 } \\
\text { 安定 }\end{array}$ \\
\hline $\begin{array}{l}\text { 八臭化物以上 } \\
\left(\begin{array}{l}\text { 熱ベンゼン } \\
\text { 不溶性 }\end{array}\right)\end{array}$ & 13.2 & 固体 & 白色 & $\begin{array}{l}225 \sim 240 \\
\left(\begin{array}{l}\text { 分解 } \\
\text { 黑変 }\end{array}\right)\end{array}$ & 69.8 & 安定 \\
\hline
\end{tabular}

臭素（\%）はカリウス氏法によった。

脱臭素上記のようにして得た四つの臭化物をとれ ぞれ同量の亜鉛末と 15 倍量のメタノール中で $5 N$ メタ ノール性塩酸を滴下しながら逆流冷却器をつけて軽く煮 沸させ数時間脱臭反応を行った。この際, 低度の臭化物 では比較的簡単飞脱臭素されたが，不飽和度の高い脂肪 酸の臭化物で柱反応が非常に䅂そく, 特に八臭化物では 反応がすこぶる困難であった。よって亜鉛末にアルコー ル性塩酸の反応物を吸引口別し，口湤からは常法に従い
脱臭素物を収得し，一方口紙上の残サはさらに 5 倍量の 氷酢酸と同量の亜鉛末をるって処理し， $20 \mathrm{hr}$ 反応させ たのちロ過し，口液より減圧下で氷酢酸を除去したのち エーテル抽出を行い脱臭素物を得た。脱臭素の反応条 件，収率は表-7 のと和りである。

\section{表-1}

\begin{tabular}{|c|c|c|c|c|c|}
\hline $\begin{array}{l}\text { 試 料 } \\
\text { 臭化物 }\end{array}$ & 脱臭素法 & $\begin{array}{l}\text { 反応 } \\
\text { 時間 } \\
\text { (hr) }\end{array}$ & $\begin{array}{c}\text { 処理量 } \\
(\mathrm{g})\end{array}$ & $\left|\begin{array}{|c|}\text { 脱臭素 } \\
\text { 物収量 } \\
(\mathrm{g})\end{array}\right|$ & 収率 (\%) \\
\hline 二臭化物 & $\begin{array}{l}\text { 亜鉛末ーメタ } \\
\text { ノール壏酸 }\end{array}$ & 3 & 548 & 203.4 & 61.7 \\
\hline 四臭化物 & " & 3 & 91 & 27.7 & 77.4 \\
\hline 六臭化物 & " & 5 & 25 & 6.4 & 78.0 \\
\hline 八臭化物 & " & 10 & 129 & 2.3 & 5.9 計 \\
\hline 八臭化物 & $\begin{array}{l}\text { 要鉛末, 水 } \\
\text { 酩酸 }\end{array}$ & 20 & (129) & 18.1 & $46.2^{52.1}$ \\
\hline
\end{tabular}

またこのようにして得た脱臭素物の性状は 表-8 のと 捛りである。

表-8

\begin{tabular}{|c|c|c|c|c|c|}
\hline 脱臭素物 & 色相 & $\begin{array}{c}\text { 屈折率 } \\
n_{\mathrm{D}}^{20}\end{array}$ & ケン化価 & $\left.\mid \begin{array}{l}\exists \text { ウ素価 } \\
(\text { ス } 1\} \\
\text { ス法 }\end{array}\right) \mid$ & $\begin{array}{l}\text { 液体酸* } \\
\text { 分布率 }\end{array}$ \\
\hline モノエン系列 & 赤橙 & 1.4 & 187.3 & 103.3 & 79.3 \\
\hline ジエン系列 & 赤橙 & 1.5009 & 190.8 & 194.7 & 8.9 \\
\hline トリエン系列 & 黄橙 & 1.4934 & 204.1 & 248.8 & 2.2 \\
\hline $\begin{array}{l}\text { テトラエン系 } \\
\text { 列以上 }\end{array}$ & $\begin{array}{l}\text { 赤 } \\
\text { カッ }\end{array}$ & 1.4893 & 171.4 & 301.6 & 9.5 \\
\hline
\end{tabular}

* 臭化物収量扣よび臭素含量より計算

上表に括いては(飽和特よび)モノエン系列の脱臭素物 のヨウ素価がかなり高く，乙か子後記するように，相当 量の飽和酸を混有している。よってオレイン酸よりもさ らに高い不飽和度の脂肪酸を混有しているものと見なし ろる。

\section{石油エーテル可溶性臭化物から採取した不飽和酸の検} 索

上記のようと石油エーテル可溶性臭化物より得た脂肪 表-9

\begin{tabular}{|c|c|c|c|c|c|c|}
\hline 分番号 & $\mid \begin{array}{c}\mathrm{m}^{\mathrm{m}} \text { 温度 } \\
\left({ }^{\circ} \mathrm{C}\right)\end{array}$ & $\begin{array}{c}\text { 压力 } \\
\left(\begin{array}{c}\mathrm{mm} \\
\mathrm{Hg}\end{array}\right)\end{array}$ & $\begin{array}{c}\text { 収量 } \\
(\mathrm{g})\end{array}$ & $\begin{array}{c}\text { 屈折率 } \\
n_{\mathrm{D}}^{20}\end{array}$ & $\begin{array}{l}\text { ケン } \\
\text { 化価 }\end{array}$ & 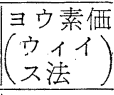 \\
\hline (1) & $\sim 146$ & 7 & 8.1 & 1.4453 & 243.4 & 57.1 \\
\hline$(2)$ & $147 \sim 156$ & 7 & 13.7 & 1.4492 & 209.4 & 77.9 \\
\hline$(3)$ & $157 \sim 166$ & 6.5 & 6.2 & 1.4518 & 203.0 & 89.5 \\
\hline (4) & $167 \sim 176$ & 6.5 & 12.3 & 1.4549 & 194.9 & 100.1 \\
\hline (5) & $177 \sim 185$ & 6.5 & 12.6 & 1.4569 & 188.0 & 123.2 \\
\hline (6) & $186 \sim 194$ & 6.5 & 9 & 588 & 177.9 & 8.7 \\
\hline (7) & $195 \sim 207$ & 6.5 & 22.7 & 1.4606 & 174.0 & 100.8 \\
\hline (8) & $209 \sim$ & 6.5 & 2.0 & 1.4676 & 168.9 & 109.5 \\
\hline $\begin{array}{l}\text { 残サ拉 } \\
\text { び損失 }\end{array}$ & & & 7.5 & & & \\
\hline
\end{tabular}


表-10

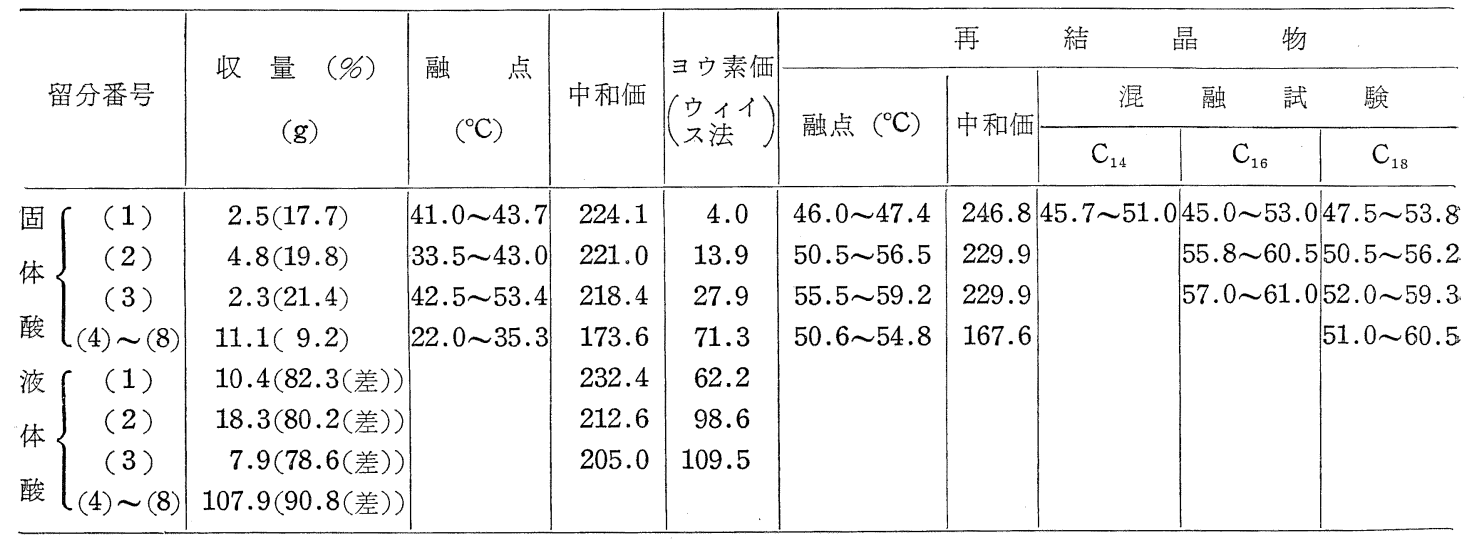

酸メチルを分別蒸留に付して 表-9 の結果を得た。

以上の数值より明らかなように, 石油エーテル可溶性 臭化物より得た脂肪酸のなか、は, 相当量の飽和酸とモ ノエン以上の不飽和酸を混有している。よって前者を鉛 塩アルコール法により, ジエンまたはとれ以上の不飽和 酸をバリウム塩ベンゼン法によって分離し，オレイン酸 系列酸を採取した (後記する)。すなわち留分 $(1)$, (2)，(3) 特よび (4)〜（8）を合一して，これより 固体酸を分離した。このようにして得た固体酸, 液体酸 の性状は 表-10のと和りである。

上記のようねして得た液体酸を合一しバリウム塭とし て $95 \%$ \%ルコール少量を含んだベンゼンより再結晶さ せ,不溶性拓よび可溶性のバリウム塩に分け,それぞれよ

\section{表-11}

\begin{tabular}{|c|c|c|c|c|}
\hline & $\begin{array}{c}\text { 収量 } \\
(\mathrm{g})\end{array}$ & $\begin{array}{c}\text { 屈折率 } \\
n_{\mathrm{D}}^{20}\end{array}$ & ケン & $\left(\begin{array}{ll}\exists \text { ウ素価 } \\
\left(\begin{array}{l}\text { ウ } \\
\text { ス法 }\end{array}\right)\end{array}\right.$ \\
\hline $\begin{array}{l}\text { ベンゼン可溶性バリ } \\
\text { ウム塩より得た脂肪 } \\
\text { 酸メチル }\end{array}$ & 93.6 & 1.4602 & 200.1 & 113.2 \\
\hline $\begin{array}{l}\text { ベンゼン不溶性バリ } \\
\text { ウム塩より得た脂肪 } \\
\text { 酸メル }\end{array}$ & 32.5 & 1.4522 & 187.6 & 79.6 \\
\hline
\end{tabular}

\section{表-12}

\begin{tabular}{|c|c|c|c|c|c|c|}
\hline 留分番号 & $\begin{array}{c}\text { 留出温度 } \\
\left({ }^{\circ} \mathrm{C}\right)\end{array}$ & $\left(\begin{array}{c}\text { 圧力 } \\
\mathrm{mm} \\
\mathrm{Hg}\end{array}\right)$ & $\left|\begin{array}{c}\text { 収量 } \\
(\mathrm{g})\end{array}\right|$ & $\begin{array}{c}\text { 屈折率 } \\
n_{\mathrm{D}}^{20}\end{array}$ & $\begin{array}{l}\text { ケン } \\
\text { 化価 }\end{array}$ & $\begin{array}{l}\exists \text { ヨ素価 } \\
\left(\begin{array}{l}\text { ウイイイ } \\
\text { ス法 }\end{array}\right)\end{array}$ \\
\hline 1 & $\sim 177$ & 11 & 2.5 & 1.4390 & 225.2 & 45.6 \\
\hline 2 & $178 \sim 188$ & 11 & 5.0 & 1.4422 & 209.0 & 61.8 \\
\hline 3 & $189 \sim 198$ & $11 \sim 12$ & 3.9 & 1.4446 & 192.5 & 69.9 \\
\hline 4 & $199 \sim 208$ & 12 & 17.5 & 1.4531 & 183.3 & 88.2 \\
\hline 5 & $209 \sim 219$ & 12 & 7.1 & 1.4557 & 174.0 & 85.2 \\
\hline 6 & $220 \sim 228$ & 12 & 9.5 & 1.4562 & 170.4 & 86.6 \\
\hline 7 & $229 \sim$ & 12 & 1.8 & 1.4577 & 224.9 & 81.4 \\
\hline $\begin{array}{l}\text { 残サおよ } \\
\text { び損失 }\end{array}$ & & & 3.7 & & & \\
\hline
\end{tabular}

表-13

\begin{tabular}{|c|c|c|c|c|c|c|}
\hline 分番号 & $\mid \begin{array}{c}\text { 留出温度 } \\
\left({ }^{\circ} \mathrm{C}\right)\end{array}$ & $\begin{array}{c}\text { 圧力 } \\
\left(\begin{array}{c}\mathrm{mm} \\
\mathrm{Hg}\end{array}\right)\end{array}$ & $\left|\begin{array}{l}\mid \text { 収量 } \\
(\mathrm{g})\end{array}\right|$ & $\begin{array}{c}\text { 屈折率 } \\
n_{\mathrm{D}}^{20}\end{array}$ & $\begin{array}{l}\text { ケン } \\
\text { 化価 }\end{array}$ & $\begin{array}{l}\exists \text { ウ素価 } \\
\left(\begin{array}{c}\text { 门 } \\
\text { ス法 }\end{array}\right)\end{array}$ \\
\hline $1^{\prime}$ & 186 & 12 & 8.7 & 1.4510 & 224.6 & 86.1 \\
\hline $2^{\prime}$ & $189 \sim 199$ & 12 & 5.4 & 1.4520 & 220.4 & 95.4 \\
\hline $3^{\prime}$ & $200 \sim 214$ & 11 & 3.2 & 1.4 & 211.2 & 120.6 \\
\hline $4^{\prime}$ & $176 \sim 185$ & 6.5 & 14.9 & 1.4 & 194.1 & 105.6 \\
\hline $5^{\prime}$ & $186 \sim 199$ & 6.5 & 26.0 & 1.4 & 193.6 & 104.0 \\
\hline $6^{\prime}$ & $200 \sim 211$ & 6.5 & 11.0 & 1.4620 & 178.2 & 124.1 \\
\hline $7^{\prime}$ & $212 \sim 219$ & 6.5 & 6.4 & 1.4641 & 175.6 & 124.0 \\
\hline $8^{\prime}$ & $220 \sim$ & 6.5 & 3.9 & 1.4680 & 175.7 & 118.0 \\
\hline $\begin{array}{l}\text { サ扮よ } \\
\text { 損失 }\end{array}$ & & & 8.1 & & & \\
\hline
\end{tabular}

り脂肪酸を収得しついでメチルエステルとし分別蒸留に 付した。各メチルエステルの収量, 性状を表一11に示す。 ベンゼン不溶性バリウム塩より得た脂肪酸メチルの分 留結果は 表-12 のと物りであり, またベンゼン可溶性 バリウム塩より得た脂肪酸メチルの分留結果は䘚-13の と括りである。

蒸留の最後の留分のケン化価は値が少し高く出ている が，これはしばしば経験することである。以上各留分の ろち定数の近似しているものを合一してェライジン化試 験を行った結果を 表-14 そ示すे。

\section{表-14}

\begin{tabular}{c|c|c|c}
\hline 留分番号 & 融 点 $\left({ }^{\circ} \mathrm{C}\right)$ & 中和価 & $\begin{array}{c}\text { ヨウ素価 } \\
\text { (ウイス法) }\end{array}$ \\
\hline 4 & $44.8 \sim 47.2$ & & \\
$5+6$ & $42.5 \sim 45.5$ & 193.9 & \\
$1^{\prime}+2^{\prime}$ & $37.5 \sim 42.1$ & & \\
$3^{\prime}$ & —* & & \\
$4^{\prime}+5^{\prime}$ & 一* & & \\
$6^{\prime}+7^{\prime}$ & $43.5 \sim 46.6$ & 180.6 & 75.8 \\
\hline
\end{tabular}

*固化せず 


\section{石油エーテル不溶性臭化物の検索}

石油エーテル不溶性臭化物より亜鉛末とメタノール性 塩酸により脱臭素して得た脂肪酸メチルの分留結果を 表-15 飞示す。

表-15

\begin{tabular}{|c|c|c|c|c|c|c|}
\hline 留分番号 & $\begin{array}{c}\text { 留出温度 } \\
\left(\begin{array}{l}{ }^{\circ} \mathrm{C} / \\
7 \mathrm{mmHg}\end{array}\right)\end{array}$ & \begin{tabular}{|l|} 
收量 \\
$(\mathrm{g})$
\end{tabular} & $\mid \begin{array}{c}\text { 比重 } \\
d_{4}^{15}\end{array}$ & 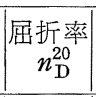 & $\begin{array}{l}\text { ケン } \\
\text { 化価 }\end{array}$ & $\begin{array}{l}\exists \text { ウ素価 } \\
\left(\begin{array}{l}\text { ウ } \uparrow \\
\text { ス法 }\end{array}\right)\end{array}$ \\
\hline 1 & $156 \sim 190$ & 3.3 & 0.9140 & 1.4690 & 193.3 & 209.9 \\
\hline 2 & $191 \sim 205$ & 3.9 & 0.9358 & 1.4806 & 180.1 & 208.1 \\
\hline 3 & $206 \sim 218$ & 2.8 & & 1.4878 & 172.1 & 210.2 \\
\hline $\begin{array}{l}\text { 残サ和よ } \\
\text { び損失 }\end{array}$ & & 10.0 & & & & \\
\hline
\end{tabular}

以上飞招いてケン化価は $\mathrm{C}_{18} \sim \mathrm{C}_{22}$ の酸と相当し, ヨ ウ素価はジンとトリエンの中間市る。

ベンゼン可溶性臭化物よりの脂肪酸メチルは少量のた め分留を行充なかった。

つぎそベンゼン不溶性多臭化物より亜鉛末と醮酸で脱 臭素して得た脂肪酸メチルを $10^{-3} \mathrm{~mm} \mathrm{Hg}$ の高度真空飞 特いて分留した結果は表-16のと招りである。

表-16 の留分 (1) の紫外部吸収を測定し 図-1 の曲 表-16

\begin{tabular}{|c|c|c|c|c|c|c|c|}
\hline $\begin{array}{l}\text { 留分 } \\
\text { 番号 }\end{array}$ & $\begin{array}{l}\text { 留出* } \\
\text { 温度 } \\
\left({ }^{\circ} \mathrm{C}\right)\end{array}$ & \begin{tabular}{|c|} 
圧力 \\
$(\mathrm{mm}$ \\
$\mathrm{Hg})$
\end{tabular} & $\mid \begin{array}{l}\text { 収量 } \\
\text { (g) }\end{array}$ & $n_{\mathrm{D}}^{20}$ & $d_{4}^{15}$ & $\begin{array}{l}\text { ケン } \\
\text { 化価 }\end{array}$ & 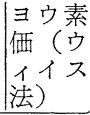 \\
\hline 1 & $|127 \sim 142|$ & $10^{-3}$ & 3.6 & 1.4818 & 0.9255 & 188.7 & 318.4 \\
\hline 2 & $142 \sim 165$ & $10^{-3}$ & 5.3 & 1.4895 & 0.9273 & 178.6 & 335. \\
\hline 3 & $165 \sim 188$ & $10^{-3}$ & 1.0 & 1.4964 & & 170.9 & 334 \\
\hline $\begin{array}{l}\text { 残サ特 } \\
\text { 上び指 } \\
\text { 失 }\end{array}$ & & & 5.6 & & & & \\
\hline
\end{tabular}

* 蒸留器内液温を示す。

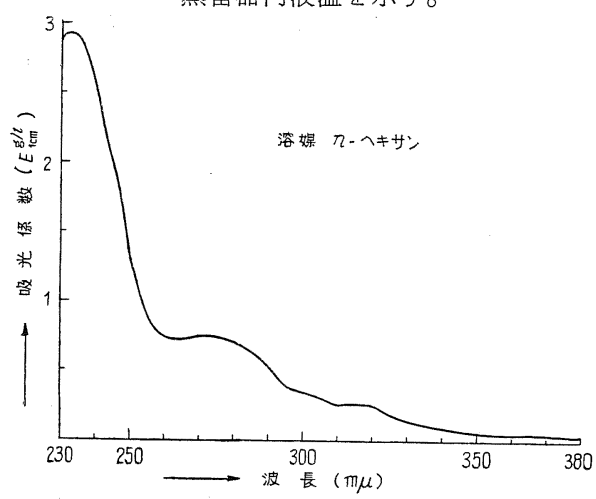

図-1
線を得た。

以上のようとして得た各留分をエタノールを溶媒とし てラネーニッケル（川上研究所製）を触媒として常温 で 9 32 hr, 振とろして水素添加在行い，白色ないし 淡黄色の固体脂肪酸エステル得た。このもののケン化 価, ヨウ素価ならびそこれをケン化後酸分解して得た脂 肪酸を $75 \%$ エタノールより 三回再結晶して得た白色結 晶の融点を表-17 亿示す。

\section{表-17}

\begin{tabular}{|c|c|c|c|c|c|c|c|}
\hline \multirow{2}{*}{ 試 } & & \multirow{2}{*}{$\begin{array}{l}\text { ケン } \\
\text { 化価 }\end{array}$} & \multirow{2}{*}{ 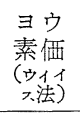 } & \multirow{2}{*}{$\begin{array}{l}\text { 融点 } \\
\left({ }^{\circ} \mathrm{C}\right)\end{array}$} & \multicolumn{3}{|c|}{ 混 融 試 験 } \\
\hline & & & & & $\mathrm{C}_{16}$ & $\mathrm{C}_{18}$ & $\mathrm{C}_{22}$ \\
\hline \multicolumn{2}{|c|}{$\begin{array}{r}\text { シエン酸留分 } \\
(1)\end{array}$} & 191.3 & 8.9 & $\left|\begin{array}{l}63.5 \\
\sim 64.5\end{array}\right|$ & $\left|\begin{array}{|c|}54.3 \\
\sim 57.5\end{array}\right|$ & $\begin{array}{l}62.5 \\
565.6\end{array}$ & $6 \mid \begin{array}{l}64.1 \\
669.4\end{array}$ \\
\hline \multirow{4}{*}{\multicolumn{2}{|c|}{$\begin{array}{l}\text { トリエン酸 } \\
\text { テトラエン酸留分 }\end{array}$}} & 183.0 & 10.9 & $\begin{array}{l}71.0 \\
\sim 71.5\end{array}$ & & $\begin{array}{l}62.8 \\
\sim 64.8\end{array}$ & $\begin{array}{c}69.0 \\
8 \sim 76.4\end{array}$ \\
\hline & & 169.7 & 25.8 & $\begin{array}{l}75.6 \\
\sim 79.0\end{array}$ & & & $\begin{array}{l}75.5 \\
\sim 77.6\end{array}$ \\
\hline & & 173.5 & 32.2 & $\begin{array}{l}66.4 \\
\sim 74.8\end{array}$ & & $\begin{array}{l}61.2 \\
\sim 67.5\end{array}$ & \begin{tabular}{c|c}
68.4 \\
5
\end{tabular} \\
\hline & & 187.2 & 4.6 & $\begin{array}{l}62.8 \\
\sim 64.5\end{array}$ & $\begin{array}{l}55.8 \\
\sim 59.2\end{array}$ & $2 \quad 63.4$ & $\begin{array}{ll}67.8 \\
0 \sim 74.9\end{array}$ \\
\hline & (2) & & 4.5 & $\begin{array}{l}68.5 \\
\sim 69.0\end{array}$ & $\begin{array}{l}57.5 \\
\sim 57.8\end{array}$ & $8 \begin{array}{l}61.8 \\
\sim 62.7\end{array}$ & $\begin{array}{l}73.1 \\
736.9\end{array}$ \\
\hline & (3) & 164.4 & 17.7 & $\begin{array}{l}85.0 \\
\sim 88 .\end{array}$ & & & $\begin{array}{l}69.7 \\
\sim 77.6\end{array}$ \\
\hline
\end{tabular}

以上飞よりジエン酸留分 (3) 打よびテトラエン酸留 分 (2) は $\mathrm{C}_{22}$ 酸飞当り, 艺の他のシェン酸留分 (1) を除く以外のるのは大体 $\mathrm{C}_{22}$ 亿近似する。よって $\mathrm{C}_{22}$ 酸 の存在を確認する。

\section{総括}

ミンク鯨油中の脂肪酸は, 飽和酸は括も飞 $\mathrm{C}_{16}, \mathrm{C}_{18}$ 酸よりなる。これより分子量の大きいるのも少量は現存 する。液体酸は括るとモノエン, ジエン, トリエン, テ トラエン酸よりなる。ペンタエン酸以上のものもあるで あろろが微量と考学る。ジエン酸では $\mathrm{C}_{18}, \mathrm{C}_{20}, \mathrm{C}_{22}$ の 存在が考克られる。テトラエン酸では $\mathrm{C}_{16}, \mathrm{C}_{18}, \mathrm{C}_{22}$ の 存在が考兄られる。 $\mathrm{C}_{20}$ も存在するであろう。トリエン 酸では $\mathrm{C}_{18}, \mathrm{C}_{20}$ 酸の存在が考克られる。( $\mathrm{C}_{16}$ 正多分存 在するであるう)。

付記 吸収スペクトルは土屋知太郎博士の厚意により 测定したるのである。

（昭和 33 年 2 月 3 日受理） 